\title{
Kompetencja gramatyczna w nauczaniu języka słowackiego jako obcego
}

\section{Katarína Dudová, Prehl'ad slovenskej morfosyntaxe s cvičeniami, Univerzita Konštantína Filozofa, Nitra 2015, 104 s.}

Praca Kataríny Dudovej z Uniwersytetu Konštantína Filozofa w Nitrze (Słowacja) Prehl'ad slovenskej morfosyntaxe s cvičeniami powstała w ramach projektu „Nitriansky model skvalitnenia vyučvania slovenského jazyka a literatúry na školách s vyučovacím jazykom národnostných menšín metódou vyučovania cudzích jazykov (s dôrazom na školy s vyučovacím jazykom mad’arským)". Projekt był realizowany przez zespół ekspertów z dziedziny nauczania języka słowackiego (nauczycieli akademickich, lingwistów, literaturoznawców) od stycznia 2014 roku do czerwca 2015 roku. Szczegółowe informacje dostępne są na stronie internetowej $<$ http:// www.ksj.ff.ukf.sk/nitriansky-model>.

Rezultatem projektu było: po pierwsze, opracowanie adekwatnych podstaw metodologicznych nauczania języka słowackiego jako obcego, po drugie przygotowanie podręczników dla przyszłych nauczycieli języka słowackiego z zakresu nauczania poszczególnych sprawności językowych.

Podręcznik Prehl'ad slovenskej morfosyntaxe... stanowi źródło materiałowe dla nauczycieli języka słowackiego jako obcego w szkołach z wykładowym językiem węgierskim. Konstrukcja podręcznika i jego treści wyraźnie wskazują, że może być użyteczny również w innych grupach, np. na lektoratach języka słowackiego poza granicami Słowacji. W tym kontekście oceniam recenzowaną pracę jako wysoce przydatną w nauczaniu gramatyki opisowej języka słowackiego na studiach słowacystycznych w Polsce.

Jednostki językowe wspólne dla morfologii i składni zaliczane są w słowackiej literaturze przedmiotu do podsystemu nazywanego morfosyntax. Obejmuje on dyscyplinę graniczną, w której kryteria morfologiczne 
i syntaktyczne wykorzystywane do opisu i objaśniania zjawisk językowych często przeplatają się ze sobą w praktyce komunikacyjnej.

Nauczanie języka obcego opiera się na rozwijaniu umiejętności zdobywania i przekazywania informacji przy jednoczesnym zachowaniu poprawności i skuteczności przekazu. Należy więc zwracać szczególną uwagę na prawidłowe opanowanie systemu gramatycznego, którego znajomość przyczynia się w dużym stopniu do prawidłowego przekazywania treści w języku obcym. Osoba ucząca się języka obcego powinna posiadać rozwiniętą kompetencję lingwistyczną, na którą składa się wiedza gramatyczna, polegająca na znajomości i umiejętności stosowania gramatycznych środków językowych, umiejętności rozumienia i wyrażania znaczeń za pomocą odczytywania i tworzenia odpowiednio skonstruowanych wyrażeń i zdań zgodnie z tymi zasadami. Nauczanie gramatyki powinno polegać na zapoznaniu uczących się ze strukturami języka oraz z zastosowaniem tych struktur w zdaniu. Proces ten przebiega w trzech etapach: prezentacja, utrwalanie i stosowanie w praktyce struktur gramatycznych. Jest to model typowy dla nauczania języka obcego od podstaw. W podręczniku Prehl'ad slovenskej morfosyntaxe... autorka skupia się na dwóch etapach nauczania gramatyki: utrwalaniu i stosowaniu form gramatycznych w kontekstach komunikacyjnych. To podejście determinuje dobór ćwiczeń w podręczniku.

Podręcznik składa się z 11 części, które, poza rozdziałem I, są zbiorem ćwiczeń gramatycznych z krótkim wprowadzeniem teoretycznym. Całość została uzupełniona o klucz do ćwiczeń. Struktura pracy oparta jest na podziale na odmienne i nieodmienne części mowy w języku słowackim.

W rozdziale I autorka wyjaśnia niektóre terminy podsystemu morfologicznego i składniowego języka słowackiego w konfrontacji z językiem węgierskim (deklinację, koniugację, syntagmy, typy wypowiedzeń, szyk wyrazów w zdaniu). Celem prezentowanych treści jest zwrócenie uwagi na różnice pomiędzy niektórymi elementami systemu języka aglutynacyjnego i fleksyjnego. Kolejne rozdziały (II-XI) poświęcone są poszczególnym częściom mowy, odpowiednio: rzeczownikom (podstatné mená/substantiva), przymiotnikom (prídavné menáladjektiva), zaimkom (zámenál pronominá), liczebnikom (číslovky/numeráliá), czasownikom (slovesál verbá), przysłówkom (príslovky/adverbiá), przyimkom (predložky/prepozície), spójnikom (spojky/konjunkcie), partykułom (časticelpartikuly) i wykrzyknikom (citoslovcia/interjekcie). 
Rozdział o rzeczowniku jest najobszerniejszy, zarówno pod względem prezentacji treści teoretycznych, jak i ćwiczeń praktycznych. Został podzielony na dwie części poświęcone gramatycznej kategorii rodzaju rzeczownika oraz wzorów deklinacyjnych charakterystycznych dla języka słowackiego, co koresponduje z istotnymi elementami różniącymi gramatykę języka słowackiego od gramatyki węgierskiej. Część praktyczną rozdziału poprzedzają informacje o deklinacji słowackiego rzeczownika (opartej na kategorii rodzaju gramatycznego i rodzaju naturalnego) oraz prezentacja podstawowych dwunastu wzorów deklinacyjnych, uzupełnionych o paradygmaty rzadsze (kuli, gazdiná, pani, mat'). Rozdział charakteryzuje się zróżnicowanymi typami ćwiczeń gramatycznych, co niewątpliwie korzystnie wpływa na proces przyswajania struktur gramatycznych. Prezentowane ćwiczenia oparte są na technikach automatyzujących: imitacji, substytucji i na technikach transformacyjnych, wśród których przeważają transformacje morfosyntaktyczne.

Rozdział III Prídavné mená poświęcony jest przymiotnikom słowackim w dwóch aspektach: po pierwsze - autorka zwraca uwagę na kongruencję przymiotnika z rzeczownikiem (temu zagadnieniu poświęca dwa ćwiczenia), po drugie - omawia wzory deklinacyjne przymiotnika, podkreślając odmianę przymiotników jakościowych (akostných), relacyjnych (vzt’ahových) i dzierżawczych (privlastňovacích). Ważną dziedziną w nauczaniu gramatyki języka słowackiego (treści poświęconych przymiotnikom) jest ortografia, zwłaszcza problemy z pisaniem miękkiego i twardego $i\left(i / i^{\prime}: y / y^{\prime}\right)$. W rozdziale poświęconym zaimkom autorka zawarła ćwiczenia poświęcone odmianie zaimków osobowych, dzierżawczych i zwrotnych (osobné, privlastňovacie i zvratné zámená), które systematyzują wiadomości o używaniu form enklitycznych i proklitycznych, a także zwracają uwagę na specyficzne dla języka słowackiego (w porównaniu z językiem węgierskim) długie i krótkie postaci zaimków. Omawiana część zawiera również ćwiczenia doskonalące użycie w tekście zaimków wskazujących, pytających, przeczących, upowszechniających i nieokreślonych (ukazovacie, opytovacie, vymedzovacie i neurčité zámená). Obejmuje ćwiczenia transformacji morfosyntaktycznych i słowotwórczych (np. ćw. 4.2.4, s. 43). Liczebniki stanowią kolejną nominalną część mowy prezentowaną w podręczniku, której opanowanie jest dla uczących się gramatyki słowackiej niejednokrotnie trudne. Chodzi tu m.in. o łączną bądź rozdzielną 
pisownię liczebników w odmianie lub o użycie odpowiedniej formy liczebnika z rzeczownikiem w zależności od rodzaju gramatycznego i funkcji syntaktycznej w zdaniu (np. Včera prišli do školy dvaja študenti. Do miestnosti vstúpilo tridsat’šest' mladých l'udí. Dostala kyticu od štyridsiatich dvoch žiakov. Pät'strojov poháñalo motor).

Czasownikom poświęcony został rozdział VI podręcznika, w którym autorka omawia kilka podstawowych kwestii z zakresu fleksji: prezentuje podział na czasowniki pełnoznaczne $\mathrm{z}$ dopełnieniem i bez dopełnienia, niepełnoznaczne i zwrotne (plnovýznamové predmetové i bezpredmetové, neplnovýznamové, zvratné slovesá). Treści teoretyczne poparte są ćwiczeniami transformacji morfosyntaktycznych i syntaktycznych (np. ćw 6.2.3, s. 52, polegające na tworzeniu zdań złożonych z odpowiednią formą czasownika modalnego chciet', czy ćw. 6.3.1, w którym zadaniem studenta jest utworzenie formy strony bierno-zwrotnej [zvratné pasívum]). Cennym dopełnieniem omawianego rozdziału są dwie części poświęcone kategoriom leksykalno-gramatycznym i gramatycznym czasowników: aspektowi, intencji, czasowi, trybowi, stronie, osobie i kongruencji. Autorka przedstawia aspekt jako kategorię transformacyjną, zmieniającą formę czasownika, intencję natomiast („spájatel'nost' slovies s inými slovami, ktoré majú na slovesnom deji účast", s. 55) opisuje na tle sześciu typów intencyjnych czasowników słowackich. Ostatni fragment rozdziału VI jest poświęcony określonym i nieokreślonym formom czasownikowym, które wyodrębniane są na podstawie kategorii czasu i trybu. Do form nieokreślonych należy bezokolicznik (neurčitok), imiesłowy (prechodnik, činné pričastie prítomné, činné príčastie minulé, trpné pričastie) i rzeczowniki odczasownikowe (slovesné podstatné meno).

Słowa pełnoznaczne wyrażające stosunek do cech dynamicznych (czasowników: rýchlo bežal, otočil sa v pravo i przymiotników: celkom dobrý, úplne slabý) - przysłówki, są przedmiotem zainteresowania autorki w rozdziale VII. Zwraca ona uwagę na podział przysłówków oraz na kategorię stopnia. Ćwiczenia automatyzujące mają charakter transformacji słowotwórczych oraz syntaktycznych.

Nieodmiennym częściom mowy poświęcone są rozdziały VIII-XI, w których zaprezentowany został podział przyimków na pierwotne i wtórne (prvotné a druhotné predložky); spójników na współrzędne i podrzędne (prirad'ovacie a podrad'ovacie spojky); partykuł na wprowadzające 
i wyodrębniające (uvádzacie a vytyčovacie častice). W rozdziale XI, o wykrzyknikach, zadaniem studentów/uczniów jest transformacja wykrzykników w inne części mowy, określenie funkcji syntaktycznej oraz napisanie własnego tekstu z wykorzystaniem podanych wykrzykników.

Pracę kończy wykaz literatury obejmujący siedemnaście pozycji z zakresu morfologii i składni współczesnego języka słowackiego. Załącznikiem do omawianego podręcznika jest informacja Márii Alabánovej i Marcela Olšiaka o projekcie, w którego ramach powstała recenzowana praca.

Sprawnie przebiegający proces dydaktyczny powinien obejmować wiele współgrających ze sobą elementów. Poza opanowaniem kompetencji gramatycznej, na której skupia się omawiany podręcznik, istotną składową nauczania języka obcego jest testowanie, dzięki któremu ocenia się stopień przyswojenia treści, a tym samym skuteczność nauczania jako całości. Ćwiczenia zaproponowane przez Katarínę Dudovą mogą zatem z powodzeniem stanowić podstawę tworzenia testów z zakresu nauczania języka słowackiego dla studentów innych narodowości. Podsumowując: podręcznik Prehl'ad slovenskej morfosyntaxe s cvičeniami jest przydatną i godną polecenia pomocą do nauczania języka słowackiego (również jako obcego), ze szczególnym uwzględnieniem kształcenia kompetencji gramatycznej. 